\title{
Managing Viral Respiratory Tract Infections in Lung Transplant Recipients
}

\author{
Macé Matthew Schuurmans, Christian Benden, Lars Christian Huber
}

Division of Pulmonology, Zurich University Hospital, Zurich, Switzerland

\begin{abstract}
Lung transplant recipients require life-long profound immunosuppression, making them prone to respiratory tract infections (RTIs), in particular viral infections, during the winter season. Since RTIs may have severe consequences, of which acute or chronic allograft dysfunction is feared most, early diagnosis and treatment are recommended. Patients monitor lung function daily at home and are instructed to contact the transplant center in case of signs and symptoms suspicious of RTIs. We then obtain nasopharyngeal swabs for viral and bacteriological examination and initiate pre-emptive treatment with antivirals, broadband antibiotics, and sometimes intravenous immunoglobulins. Treatment duration is guided by virology sampling results. As preventive measures, we provide vaccination against seasonal influenza for patients and household contacts and recommend specific daily hygiene measures.
\end{abstract}

Keywords: Antibiotic, antivirals, immunosuppression, lung transplantation, viral infection

\section{Özet}

Akciğer nakil olguları, hayat boyu yoğun bir immünsuresif tedavi almak zorundadırlar. Bu tedavi onları, özellikle kış döneminde, başta viral nedenler olmak üzere, solunum yolu enfeksiyonlarına (SYE) yatkın hale getirir. Solunum yolu enfeksiyonlarının, akut veya kronik allograft rejeksiyonu gibi çok ağır ve korkulan sonuçları olabileceği için, erken tanı ve tedavi önerilmektedir. Tüm akciğer nakil olguları evlerinde günlük solunum fonksiyonu takibi yaparlar. Bu takip sırasında SYE şüphesi doğuracak semptom ve bulgular görüldüğünde nakil merkezi ile hemen bağlantı kurmaları konusunda eğitimlidirler. Nakil merkezine SYE şüphesi ile başvuran hastadan viral ve bakteriyolojik inceleme için nazofarengeal sürüntü alını. Sonrasında önlem olarak geniş spektrumlu antibiyotik, antiviral ve intravenöz immünglobülin tedavi başlanır. Tedavi süresi virolojik örneklemelerin sonuçlarına göre belirlenir. Ayrıca SYE'den korunmak için tüm nakil olgularımıza ve ev içi temaslılarına mevsimsel influenza aşısı yapılır ve özel hijyen önlemleri önerilir.

Anahtar Kelimeler: Akciğer transplantasyonu, antibiyotik, antiviral, immünosüpresyon, viral enfeksiyon
Received Date / Alındığ Tarih: 05.05.2014 Accepted Date / Kabul Tarihi: 03.07.2014 Available Online Date /

Çevrimiçi Yayın Tarihi: 25.11.2014

Address for correspondence / Yazışma Adresi Macé Matthew Schuurmans, Division of Pulmonology, Zurich University Hospital, Zurich, Switzerland E-mail / E-posta: mace.schuurmans@usz.ch

(C) Copyright 2014 Turkish Respiratory Society (TRS) Eurasian J Pulmonol 2014

DOI: 10.5152/ejp.2014.87597

- Available online at www.eurasianjpulmonol.com

\section{INTRODUCTION}

Lung transplantation is an established therapy for end-stage non-malignant pulmonary disease. Long-term survival rates are inferior than for other solid organ transplant recipients (SOTRs), with the overall median survival being slightly more than 5 years. The most important long-term complication is the development of chronic lung allograft dysfunction (CLAD), most commonly presenting as bronchiolitis obliterans syndrome (BOS). This development is, at least in part, due to inflammation in the small airways that results in structural and functional changes of the lung with an obstructive airway pattern. The etiology of BOS and its pathogenesis are incompletely understood. Triggers of inflammatory reactions, such as repeated acute rejection episodes or respiratory tract infections, however, appear to be contributing factors.

Lung transplant recipients (LTRs) are more susceptible to infections in comparison to other SOTRs, which implicates a greater impact of respiratory tract infections (RTIs) on the long-term functional outcome $(1,2)$. For these reasons, infectious complications are feared in these severely immunosuppressed individuals $(3,4)$. A causative link between viral infections and rejection has long been assumed (5). To date, no study has been able to prove that a particular respiratory virus infection is directly linked to either acute rejection or the development of CLAD. The development of CLAD appears to be more likely a process of unspecific inflammatory reactions triggered by RTIs rather than virus-specific factors (6). A number of studies have shown that RTIs of viral origin are associated with the development of BOS as long-term sequelae. A few authors have described acute rejection episodes in LTRs associated with certain viral RTIs. This is in line with our own experience. However, the data sup- 
porting this link are controversial. It might be that a sequence of various different RTIs is more likely to contribute to allograft dysfunction over time, and some RTIs may be more prone to trigger this development than others. In addition, susceptibility to this development may vary among LTRs, and there may be other contributing factors that promote this development, such as gastro-esophageal reflux disease with associated microaspirations. Further, prospective studies are expected to elucidate these issues. In the meantime, many experts consider early diagnosis and treatment of RTI is of crucial importance to prevent the potentially serious sequelae of these infections.

Immunosuppression puts LTRs at increased risk for viral infections. Prophylactic medication for cytomegalovirus (CMV) infections, which is widely used at least for the first 3 months post-transplant and sometimes extended beyond this phase (e.g. at our center), protects patients largely from infections of the herpes family. The increased risk for the acquisition of community-acquired respiratory virus (CARV) in LTRs is due to the life-long profound immunosuppression and the fact that the transplanted organ is in direct contact with the environment. Denervation, a reduced cough reflex, and subsequent impaired mucociliary clearance further increase the risk of severe pulmonary infections. Infections with CARV influence the acute and chronic morbidity and mortality of $\operatorname{LTRs}(7,8)$. In this article, we outline the diagnostic and therapeutic strategies used at our institution to reduce the impact of these viruses on the outcome of LTRs. Due to the limited literature in the field of practical management and lack of evidence for many of these procedures, our recommendations are largely based on experience.

\section{Clinical and Radiologic Presentation}

There is significant overlap of the symptoms of CARV infections, and it is difficult to distinguish clinically which respiratory virus is causing symptoms in a given patient. Common symptoms include cough, rhinorrhea, and dyspnea (Table 1). Viral infections often involve the upper respiratory tract. Progression of the viral infection to the lower respiratory tract is observed more frequently in immunosuppressed patients and is difficult to be differentiated from other viral co-infections or bacterial super-infections (9).

Progression from upper respiratory infection to lower respiratory infection is generally associated with more severe disease and, probably, with more serious short and long-term consequences. The risk of progression to lower tract disease is not well defined; however, it is likely to be dependent on the post-transplant time, intensity of immunosuppression, and type of virus.

The chest radiograph is non-specific and may show diffuse interstitial infiltrates but can also show airspace disease. The most common chest computed tomography finding is ground-glass attenuation; centrilobular nodules measuring 3 to $10 \mathrm{~mm}$, including a tree-in-bud appearance, can also be seen (9).

Due to immunosuppression, the clinical status and condition of the transplant recipient at presentation are not good indicators of disease severity. This means that initially clinically well-appearing LTRs with no or minor signs of URTI may experience a rapid decline in FEV1, which may go unnoticed unless pulmonary function tests are performed. Many centers recommend lung function self-monitoring, which is able to detect even minor or asymptomatic changes in lung function (200 $\mathrm{mL}$ or $10 \%)$.
Suggestive symptoms of RTIs are throat pain or pain on swallowing, rhinorrhea, (dry) cough, fever, and myalgias (10). In LTRs, a number of symptoms should be considered as possible indicators for an early stage of infection, since oligosymptomatic infections do occur. Gastrointestinal symptoms, such as nausea, vomiting, and diarrhea, have been reported, for example, in patients with influenza infection (11). In adenovirus infection, hepatitis can occur; in kidney transplant recipients, hemorrhagic cystitis has been reported. Possible clinical presentations are summarized in Table 1. If one or more of these symptoms are noted, we recommend contacting the transplant center by telephone as soon as possible (within hours) to minimize the diagnostic delay and initiate empirical therapy.

\section{Virus Biology}

At our transplant center, we test for the following viral pathogens when a respiratory tract infection is suspected: adenovirus, human bocavirus, corona virus, enterovirus, influenza virus, parainfluenza virus, human metapneumovirus, rhinovirus, and human respiratory syncytial virus (RSV). With the exception of adenovirus and bocavirus, these CARVs are single-stranded RNA viruses and show a predominantly seasonal appearance during the winter months (Table 2).

The symptoms of an RTI are often unspecific and potentially discrete. Symptoms of influenza infection have been well described for immunocompetent individuals, which affect $5 \%-20 \%$ of the population predominantly during the winter season. Conversely, the classical "influenza-like illness," with sudden onset of symptoms, including fever, dry cough, throat pain, myalgias, or headache, is, in most cases, not observed in its full presentation in LTRs. In symptomatic patients, the influenza virus is detected 5 times more often than when symptoms are absent (12).

Table 1. Symptoms and signs of respiratory viral infections

\begin{tabular}{|c|c|}
\hline \multicolumn{2}{|l|}{ Symptoms } \\
\hline & Throat irritation or pain, swallowing pain \\
\hline & Sneezing \\
\hline & Rhinorrhea/nasal obstruction \\
\hline & Cough with or without sputum production \\
\hline & Change in sputum (amount or color) \\
\hline & Fever \\
\hline & Malaise/Fatigue \\
\hline & Myalgia/limb pain \\
\hline & Headache \\
\hline \multicolumn{2}{|l|}{ Signs } \\
\hline -spirometric & $\begin{array}{l}\text { Reduction in FEV1 within } 24 \text { hours by } 200 \mathrm{ml} \text { or } \\
10 \% \text { (the smaller value is recommended as limit) }\end{array}$ \\
\hline \multirow[t]{2}{*}{ - radiologic } & $\begin{array}{l}\text { Change in chest x-ray or computed tomography } \\
\text { (opacity or effusion) }\end{array}$ \\
\hline & $\begin{array}{l}\text { (we usually do not routinely perform chest } \\
\text { imaging in these situations) }\end{array}$ \\
\hline - Lab findings & $\begin{array}{l}\text { Raised inflammatory markers (CRP, leukocytes) } \\
\text { without other focus }\end{array}$ \\
\hline
\end{tabular}


Approximately one-third of viral RTIs are caused by corona viruses. The SARS epidemic in 2002 was caused by a coronavirus, and the recent emergence of a complicated RTI is derived from this family of viruses (MERS-CoV).

Adenovirus, bocavirus, and parvovirus B19 are DNA viruses. Adenoviruses cause RTI in humans and are not limited to a certain season. They can also affect other organs, such as the eyes and gastrointestinal and urinary tracts. Human bocaviruses are associated with RTIs and gastroenteritis in children and adults. There are limited data on the importance of this pathogen, in part because it is rarely detected in LTRs.

\section{Diagnostic Tests and Meaning of Results}

Diagnostic methods for the detection of CARV have evolved in the last decade, largely improving sensitivity and specificity and, importantly, reducing time to diagnosis. Current molecular diagnostic tests allow rapid simultaneous detection of a number of viruses by multiplex polymerase chain reaction (PCR). In patients with a symptomatic $\mathrm{RTI}$, the most frequently detected viruses are: rhinovirus, parainfluenza virus, RSV, influenza virus, and coronavirus (14). Under certain circumstances, progression of the infection is more frequently observed from the upper airways to the lower airways: infection with influenza, RSV, PIV, pediatric patients, profound immunosuppression, early post-transplant period, and in patients with very low lymphocyte counts (15). Early initiation of antiviral therapy may reduce the progression to the lower airways, for example, with oseltamivir for influenza infections. Diagnostics and therapy therefore must be directed to these treatable viral infections.

We attempt to obtain samples from the hypopharynx or nasopharynx for PCR analysis and bacterial culture in order to identify the viral pathogen and possible bacterial co-infections, which may have implications on the treatment choice and duration. In severely immunosuppressed individuals, we frequently observe prolonged viral shedding of the virus, as detected by multiple consecutive PCR-positive results over extended durations.

It remains to be determined whether this PCR positivity is an expression of viable virus or merely detection of envelope protein without virulence. In individual cases, the cell culture may be able to answer this question, whereby the question still remains on whether the detected viable virus is to be considered "colonization" (i.e., persistence of virus in an asymptomatic patient). Infectivity from a clinical point of view would consider additional aspects, such as number of virions, ability to be mobilized from the location, and viability in the environment. Viral cultures are only performed if explicitly requested and justified, since these requests may be suppressed in some laboratories, since modern molecular methods, such as PCR, are generally considered to be sufficient for diagnosis, and in most cases, the viral culture is then considered to be obsolete/redundant. We require 2 negative PCR samples (taken on 2 different days, usually 1 week apart) to be negative before declaring the patient to be free of virus and abandon the isolation measures imposed during the active infection. These measures are implemented to prevent nosocomial transmission among outpatients and inpatients in the hospital setting.

\section{Evaluation in Case of Suspected Respiratory Tract Infection}

In case of symptoms and/or deterioration of home spirometry values, patients are instructed to contact the transplant center (Figure 1). The history taken is focused on symptoms, lung function measurements, presence of ill persons in the household, and contact with persons having signs of infection. In special situations (at night, inability to present at the hospital within a few hours due to lack of transport or large distance to the hospital), we instruct then to start empiric therapy immediately. In this case, the diagnostic workup is slightly delayed. Whenever possible, the diagnostic workup is performed on the same day in an emergency visit in our transplant outpatient clinic. The objective of this visit is to confirm the lung function measurement, which we perform with a handheld spirometer with a disposable mouthpiece and materials to assess the clinical status of the patient (inspection of the pharynx to note redness or secretions, verify nasal obstruction, and perform auscultation of the lungs). The sampling is performed for a virology examination by passing a plastic brush 2-3 times over a distance of $2-3 \mathrm{~cm}$ vertically along the back wall of the pharynx, putting the brush tip into the virus transport medium by breaking of the front half/tip while immersed in the transport medium, and discarding the part of the brush that was in contact with one's hands. The lid of the transport medium must be firmly closed. We bend the shaft of the brush slightly prior to unpacking it in order to allow for a less irritating swab-sampling maneuver. The bacteriological swab, which is a cotton wool-like covered tip, is moved back and forth between the tonsils at the back wall of the pharynx (2-3 times) and is then stuck into the gel-like culture medium. Laboratory diagnostics include differential white blood count (to detect lymphopenia or leukopenia), C-reactive protein, and creatinine. In case of dominant nasal symptoms, the viral sampling is performed nasally, whereby the straight brush is inserted rapidly and horizontally by about $3-5 \mathrm{~cm}$ and is then retracted immediately before putting it in the transport medium. The physician or nurse obtaining the samples should wear a surgical mask and a visor or face guard during the procedure.

\section{Therapy}

The general therapy principles for lung transplant recipients with a suspected RTI are: a) consequent pre-emptive therapy with and broad-spectrum antibiotics; i.e., a respiratory quinolone, b) repeated applications of intravenous immunoglobulin (IVIG) in case of prolonged infections, and c) a moderate modification of the immunosuppressant therapy if possible. Evidence-based specific therapies exist only for a minority of CARVs: i.e., for influenza virus infections (oseltamivir) and for parainfluenza, RSV, and metapneumovirus infections (ribavirin) (Table 3). Oseltamivir is given orally $75 \mathrm{mg} \mathrm{BD}$ (in case of kidney dysfunction with GFR $<30 \mathrm{~mL} / \mathrm{h}$ OD). Our dosing regimen for oral ribavirin is $400 \mathrm{mg} \mathrm{BD}$ for the first $48 \mathrm{~h}$ hours and then $200 \mathrm{mg} \mathrm{BD}$. The duration of the therapy is a matter of debate; some centers treat for 5-10 days, and we treat until 2 NPS samples are negative. For ribavirin, we monitor the full blood count weekly and discontinue the compound if adverse events are noted, such as anemia, nausea, or sleep disturbances.

\section{Pre-Emptive Treatment}

During the influenza season, we start oseltamivir (75 mg BD) in combination with moxifloxacin ( $400 \mathrm{mg}$ OD) empirically for patients with suspected respiratory tract infections (two or more signs or symptoms) pending the NPS results (virology/bacteriology). If the patient can not be seen on the same day, treatment is initiated prior to sampling, and sampling is then performed the following day.

\section{Intravenous Immunoglobulin (IVIG)}

LTRs frequently have reduced immunoglobulin $\mathrm{G}$ levels after transplantation. The hypogammaglobulinemia (defined in our setting as 
$\lg \mathrm{G}<7.0 \mathrm{~g} / \mathrm{L}$ as the lower limit of normal) appears not to influence the incidence of CARVs (16). It is suggested that the administration of IVIG for CARV infection results in the transfer of specific antibodies directed against viruses and thus helps accelerate the resolution of the infection. In case of bacterial super-infection (for example, with Klebsiella), IVIG would also help in the treatment of this infection.

\section{Modification of Immunosuppression}

Infection and also prolonged viral shedding are sometimes signs of "over"-immunosuppression in these patients. In case of strong lymphopenia $(<500$ cells/uL) or leukopenia ( $<3000$ cells/uL), we reduce the dose of immunosuppressants, commonly by reducing the antimetabolite. The reduction of mycophenolate mofetil is usually by one-third to one-half of the maintenance dose and is performed already when the respiratory tract infection is suspected (16). In case of progressive loss of lung function despite established antiviral and antibacterial therapy, we consider increasing the prednisone dose to counteract a possible inflammatory response. This would be considered in case of infections with orthomyxoviruses (PIF, RSV, metapneumovirus). Unlike others, we hardly ever give pulse steroid treatments in such situations, since our concept is primarily to treat the infection by all means and not to enhance immunosuppression additionally, which would further reduce the remaining immunological control of infection.

\section{Prophylactic Measures to Prevent Respiratory Tract Infection}

The recommendations provided here are based mainly on infection control measures suggested for seasonal influenza. Respecting these principles is also likely to prevent other CARV infections, and these measures might be considered to reflect universal precautions for respiratory tract infections (17). Most CARVs are transmitted by direct contact or aerosolized droplets. Incubation periods range generally from 1 to 10 days (9). Asymptomatic shedding may occur in transplant recipients. Both symptomatic and asymptomatic transplant recipients may be considered "super-spreaders" of virus, given the high viral loads of respiratory viruses found in respiratory secretions. We recommend the following measures (18):

1. Yearly influenza vaccination as soon as the vaccine is locally available. US guidelines recommend vaccination after 3 months following transplantation. We vaccinate post-transplant according to this timeline but preferably when the prednisone dose has been tapered to $<20 \mathrm{mg} / \mathrm{d}$. There is no good evidence for the optimal time point of vaccination or level of immunosuppressants influencing the vaccine response. The dose of the antimetabolite (mycophenolate), however, appears to have the greatest effect on the immunological response after vaccination [19]. One should bear in mind that the influenza vaccine and presumably also other vaccines show a reduced immunological response after transplantation due to the profound immunosuppression, thus affecting the humoral response in cases of infection. The influenza vaccination has been shown to be safe and effective in LTRs. The vaccination is also recommended for close contacts of LTRs - in particular, household contacts and also health professionals caring for these patients.

2. High-risk situations, which could lead to infection with respiratory viruses - for example, rush hour in shopping malls, restaurant, airports, train stations, or mass gatherings of persons in the cold season—should be avoided.
3. Frequent and consequent hand hygiene and cough etiquette (cough and sneezing into the elbow). Hand hygiene also entails disinfection after contact with public objects, such as door handles, shopping carts, or railings.

5. Avoid contact with ill relatives and friends, in particular with ill children, as much as possible. If contact can not be avoided, one may consider the ill contact person to wear a mask and encourage hand hygiene.

6. Early contact with the transplant center (within hours) when the first signs of an infection occur in order to allow for diagnostic sampling and initiation of therapy.

In summary, early self-referral of LTRs for microbiological sampling and initiation of pre-emptive treatment with oseltamivir and a quinolone or macrolide antibiotic during the influenza season aim to treat influenza infections early and limit the potential damage cause by these infections. Modification of treatment is performed $48 \mathrm{~h}$ later, when microbiological results are available by telephone consultation with patients. Selected other viruses are treated with antivirals and potentially intravenous immunoglobulins. Preventive measures are crucial for patients and relatives/close contacts in order to prevent infections in the first place.

\section{Ethics Committee Approval: N/A.}

Informed Consent: N/A.

Peer-review: Externally peer-reviewed.

Author contributions: Concept - M.M.S., C.B.: L.C.H.; Design - M.M.S., C.B.: L.C.H.; Supervision - M.M. S.; Resource - M.M.S.; Materials - N.A.; Data Collection\&/or Processing - N.A..; Analysis\&/or Interpretation - M.M.S., C.B., L.C.H.; Literature Search - M.M.S., L.C.H.; Writing - M.M.S., C.B.: L.C.H.; Critical Reviews - M.M.S., C.B., L.C.H.

Conflict of Interest: No conflict of interest was declared by the authors.

Financial Disclosure: The authors declared that this study has received no financial support.

\section{REFERENCES}

1. Witt $C A$, Meyers $B F$, Hachem RR. Pulmonary infections following lung transplantation. Thorac Surg Clin 2012; 22: p. 403-12. [CrossRef]

2. Renaud C., Campbell AP, Changing epidemiology of respiratory viral infections in hematopoietic cell transplant recipients and solid organ transplant recipients. Curr Opin Infect Dis 2011; 24: 333-43. [CrossRef]

3. Khalifah AP, Hachem RR, Chakinala MM, Schechtman KB, Patterson GA, Schuster DP, et al. Respiratory viral infections are a distinct risk for bronchiolitis obliterans syndrome and death. Am J Respir Crit Care Med 2004; 170: 181-7. [CrossRef]

4. Chemaly RF, Ghosh S, Bodey GP, Rohatgi N, Safdar A, Keating MJ. Respiratory viral infections in adults with hematologic malignancies and human stem cell transplantation recipients: a retrospective study at a major cancer center. Medicine (Baltimore) 2006; 85: 278-87. [CrossRef]

5. Kumar D, Erdman D, Keshavjee S, Peret T, Tellier R, Hadjiliadis D, et al. Clinical impact of community-acquired respiratory viruses on bronchiolitis obliterans after lung transplant. Am J Transplant 2005; 5: 2031-6. [CrossRef]

6. Magnusson J, Westin J, Andersson LM, Brittain-Long R, Riise GC.The impact of viral respiratory tract infections on long-term morbidity and mortality following lung transplantation: a retrospective cohort study using a multiplex PCR panel. Transplantation 2013; 95: 383-8. [CrossRef]

7. Shah PD, JF McDyer. Viral infections in lung transplant recipients. Semin Respir Crit Care Med 2010; 31: 243-54. [CrossRef]

8. Speich R, van der Bij W. Epidemiology and management of infections after lung transplantation. Clin Infect Dis 2001; 33 Suppl 1: S58-65. [CrossRef] 
9. Kumar D, Husain S, Chen MH, Moussa G, Himsworth D, Manuel O. A prospective molecular surveillance study evaluating the clinical impact of community-acquired respiratory viruses in lung transplant recipients. Transplantation 2010; 89: 1028-33. [CrossRef]

10. Bridevaux PO, Aubert JD, Soccal PM, Mazza-Stalder J, Berutto C, Rochat T, et al. Incidence and outcomes of respiratory viral infections in lung transplant recipients: a prospective study. Thorax 2014; 69: 32-8. [CrossRef]

11. Kumar D1, Michaels MG, Morris MI, Green M, Avery RK, Liu C, et al., Outcomes from pandemic influenza A H1N1 infection in recipients of solid-organ transplants: a multicentre cohort study. Lancet Infect Dis, 2010. 10(8): p. 521-6. [CrossRef]

12. Vu DL, Bridevaux PO, Aubert JD, Soccal PM, Kaiser L. Respiratory viruses in lung transplant recipients: a critical review and pooled analysis of clinical studies. Am J Transplant 2011; 11: 1071-8. [CrossRef]

13. Kaiser L., Aubert JD, Pache JD, Deffernez C, Rochat T, Garbino J, et al. Chronic rhinoviral infection in lung transplant recipients. Am J Respir Crit Care Med 2006; 174: 1392-9. [CrossRef]

14. Ison M.G. Antiviral therapies for respiratory viral infections in lung transplant patients. Antivir Ther 2012; 17: 193-200. [CrossRef]
15. Noell BC, Dawson KL, Seethamraju H. Effect of hypogammaglobulinemia on the incidence of community-acquired respiratory viral infections after lung transplantation. Transplant Proc 2013; 45: 2371-4. [CrossRef]

16. Schuurmans MM, Tini GM, Zuercher A, Hofer M, Benden C, Boehler A. Practical approach to emergencies in lung transplant recipients: how we do it. Respiration 2012; 84: 163-75. [CrossRef]

17. Danziger-Isakov LA, Husain S, Mooney ML, Hannan MM; ISHLT Infectious Diseases Council. The novel 2009 H1N1 influenza virus pandemic: unique considerations for programs in cardiothoracic transplantation. J Heart Lung Transplant 2009; 28: 1341-7. [CrossRef]

18. Huber LC, Isenring BD, Schuurmans MM. [Diagnosis, therapy and prevention of respiratory virus infections in lung transplant recipients]. Praxis (Bern 1994) 2014; 103: 453-9. [CrossRef]

19. Hayney MS, Welter DL, Francois M, Reynolds AM, Love RB. Influenza vaccine antibody responses in lung transplant recipients. Prog Transplant 2004; 14: 346-51. 